ISSN (print) 0867-2008 / ISSN (online) 239 I-75 I 2

DOI: http://dx.doi.org/10.12775/OM.2018.012

JuLIUSz RaCZKOWSKI*

Wydział Sztuk Pięknych

Uniwersytet Mikołaja Kopernika w Toruniu

ul. Sienkiewicza 30/32

PL-87100 Toruń

Poland

jracz@umk.pl

\title{
NOT ONLY THE GOLDEN GATE? A NEWLY DISCOVERED FRAGMENT FROM THE DECORATION OF THE CASTLE CHAPEL PORTAL IN ALTHAUS (STAROGRÓD) AS A CONTRIBUTION TO THE IDENTIFICATION OF CERAMIC SCULPTURE IN THE TEUTONIC ORDER'S STATE IN PRUSSIA
}

\section{KEYWORDS}

art history; the Middle Ages; military orders; Teutonic Order; Prussia; Starogród/Althaus, Malbork/Marienburg; medieval ceramic architectural sculpture

\begin{abstract}
The paper features new observations on ceramic architectural detail and ceramic sculptural elements, the most common types of finishing brick buildings in the Ordensland during the 13 th and first half of the I 4 th centuries. It presents an unpublished fragment which came to light as a result of the archaeological excavations in Starogród conducted in Kulmerland (Chełmno land) in the context of the project Castra Terrae Culmensis (2017), namely the fragment of a portal (?) sculpture of an unknown Saint. It is a minor discovery of small size, but compared to other preserved artwork of this type from around I 300 from the Teutonic Order's castles of Marienburg (today Malbork), Elbing (Elbląg), Thorn (Toruń), and Graudenz (Grudziądz), it is of great "causative power" in terms of revising our knowledge of types, manufacturing techniques, and above all, the actual layers of meaning with regard to figural decorations in the oldest Teutonic Order's strongholds in Prussia. As a result, ceramic architectural sculpture can be considered a phenomenon of much wider range than has previ-
\end{abstract}

* ORCID: https://orcid.org/0000-0003-308 I-86 is 
ously been accepted. The emphasis regarding its condition can be moved from the exceptional symbol of rank and power toward genius loci of architecture from the first phase of construction campaigns undertaken by the Teutonic Order in Prussia.

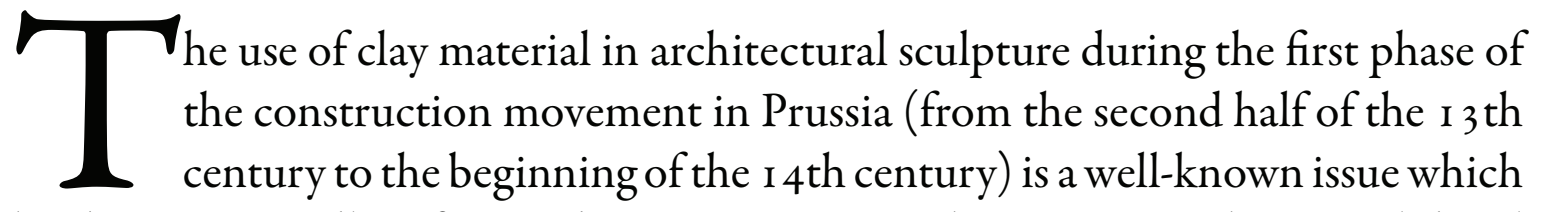
has been repeatedly referenced in previous research. Ceramic architectural detail and ceramic sculptural elements were the most common types of finishing brick buildings in the Ordensland. ${ }^{1}$ The factors for the transition from using ceramic toward using cast gypsum stone ${ }^{2}$, which took place in the Teutonic Order's sphere

I Scholars have been discussing the use of clay as a material in Gothic architectural sculpture since the inter-war years; see for example: Hubert Wilm, Gotische Tonplastik in Deutschland (Augsburg: Benno Filser, 1929). For further information on the detail from the Teutonic Order's castle in Toruń, see: Roman Domagała, "Detale architektoniczne z zamku krzyżackiego w Toruniu," in Komunikaty na sesję naukowa poświęcona dziejom sztuki Pomorza, ed. Jerzy Frycz (Toruń: Stowarzyszenie Historyków Sztuki, I 966), I 3-2 I; id., "Stała wystawa na zamku krzyżackim," Rocznik Muzeum Okregowego w Toruniu 3 (1968): I25-I29. On the architectural detail in military construction throughout the Ordensland territories, see: Marian Kutzner, "Backsteinelementen der ältesten Deutschordensburgen in Preussen," in Burgen kirchlichen Bauherren, vol. 6, ed. Wartburg-Gesellschaft zur Erforschung von Burgen und Schlössern in Verbindung mit dem Germanischen Nationalmuseum, Forschungen zu Burgen und Schlössern (München: Germanisches Nationalmuseum, 200 I), 37-48; Anna Błażejewska, Rzeźba w Prusach Krzyżackich do potowy XIV wieku. Źródta stylu (Toruń: Wydawnictwo Naukowe UMK, 20 I2), 62-ı9; Kazimierz Pospieszny, Domus Malbork: zamek krzyżacki w typie regularnym (Toruń: Wydawnictwo Naukowe UMK, 20I4),89-II2 and 23I-247; Bogusz Wasik, Budownictwo zamkowe na ziemi chetminskiej (od XIII do XV wieku) (Toruń: Wydawnictwo Naukowe $U M K, 2016$ ), $160-176$.

2 For the results of the latest research on this material within the scope of technique, technology, properties, and conditioning of its application, see: Magdalena Jakubek, "Gotyckie detale architektoniczne z zapraw gipsowych z terenu państwa krzyżackiego w Prusach. Problematyka technologiczna i konserwatorska" (PhD diss., Uniwersytet Mikołaja Kopernika, 20 I s); cf. ead., "Tzw. sztuczny kamień w średniowiecznych Prusach - nowe uwagi o materiale," in Claritas et consonantia: funkcje, formy $i$ znaczenia $w$ sztuce średniowiecza. Ksiega poświęcona pamięci Kingi Szczepkowskiej-Naliwajek w dziesiąta rocznicę śmierci, ed. Monika Jakubek-Raczkowska and Juliusz Raczkowski (Toruń-Warszawa: Wydział Sztuk Pięknych UMK/Stowarzyszenie Historyków Sztuki, 2017), 477-495. On the composition and properties of the material, see: Magdalena Jakubek, Frank Schlütter, Wioleta Oberta, and Jadwiga W. Łukasiewicz, "Medieval Gypsum Mortars Used for Architectural Details in the Castle of the Teutonic Order in Toruń, Poland," in Historic Mortars and RILEM TC 203-RHM Final Workshop HMC 2010, Proceedings of the $2^{\text {nd }}$ Conference and of the Final Workshop of RILEM TC 203-RHM, ed. Jan Válek, Caspar Groot, and John J. Hughes (Bagneux: RILEM Publications, 2009 / Red Hood, NY: Curran Associates, Inc., 20I I), 227-237; Frank Schlütter, Magdalena Jakubek, and Herbert 
of influence during the years $1320-1330$, are still being discussed. According to some researchers, this change was dictated by the need to introduce a substitute of stone and had an ideological background, ${ }^{3}$ although pragmatic considerations are equally, and perhaps even more, probable. The imprint in cast stone was a fairly pratical method; technologically, it was easier to employ while making large statues than clay firing, and it was definitely faster than stone carving. ${ }^{4}$

Obviously, the introduction of cast stone did not exclude the use of ceramic, which throughout the whole i 4 th century (and later) was employed to create architectural elements, as well as details, finishings, and flooring. Its use for architectural decoration had reached its peak much earlier. In buildings erected until the first quarter of the I 4 th century, the elements of vaults (ribs, keystones, consoles), tracery, capitals and corbels, and portal frames, some of which carry ornamental and figural reliefs, were made from clay material. The primary monumental evidence of this heritage is the Golden Gate at Malbork, preserved in most complete condition despite the intervention of restorators. The Malbork complex is also the best processed part of the remarkable legacy of the old Teutonic Order's state. ${ }^{5}$ Apart from Malbork, the portal in Bierzgłowo ${ }^{6}$ is quite well-known and discussed in the scholarship; and sculptural fragments from the

Juling, "Charakterisierung und Eigenschaften historischer Gipsmörtel aus unterschiedlichen Epochen und Anwendungsgebieten," in Gips als Baugrund, Mörtel und Dekorationsmaterial, ed. Institut für Steinkonservierung, e.V., Bericht 42 (Mainz: Institut für Steinkonservierung, e.V., 20I 2), 49-59; Frank Schlütter, "Mittelalterlicher Hochbrandgips", in 8oo Jahre Kunststein vom Imitat zum Kulturgut. Beiträge des 6. Konservierungswissenschaftlichen Kolloquiums in Berlin / Brandenburg am 8. November in Potsdam, ed. Bärbel Arnold (Worms: Potsdamer Verl.Buchhandlung, 201 2), 27-39.

3 Błażejewska, Rzeźba, i 94.

4 Juliusz Raczkowski, Monumentalne zespoty kolegium apostolskiego na terenie dawnego państwa zakonnego w Prusach (Pelplin: Wydawnictwo Bernardinum, 2013), I33-I57; id., "Kolos Malborski: problematyka warsztatowa i styloznawcza," in Monumentalna figura Madonny na kościele NMP $w$ Malborku. Konteksty historyczne, artystyczne i konserwatorskie, ed. Janusz Hochleitner (Malbork: Muzeum Zamkowe w Malborku, 2015), 83-93.

5 Bogna Jakubowska, Ztota Brama w Malborku. Apokaliptyczne bestiarium w rzeźbie średniowiecznej (Malbork: Muzeum Zamkowe w Malborku, 1989), 67-96; Bernard Jesionowski, "Opis architektury i dzieje budowlane kościoła Najświętszej Marii Panny w zespole zamkowym w Malborku," in Zamek Wysoki w Malborku. Interdyscyplinarne badania skrzydta pótnocnego, ed. Maria Poksińska (Malbork-Toruń-Łódź: Muzeum Zamkowe, 2006), 59-76; Błażejewska, Rzeźba, 71-109.

6 Teresa Mroczko, Architektura gotycka na Ziemi Chetmińskiej (Warszawa: Państwowe Wydawnictwo Naukowe, I980), I9I; Tadeusz Jurkowlaniec, Gotycka rzeźba architektoniczna w Prusach (Wrocław-Warszawa-Kraków-Gdańsk-Łódź: Wydawnictwo Polskiej Akademii Nauk, I989), 59-60; Katarzyna Zawadzka, "Portal bramy wjazdowej do zamku krzyżackiego w Bierzgłowie," Rocznik Toruński 37 (2010): 7-36; Christopher Herrmann, Mittelalterliche 
castle in Elbląg7 and lately the castle in Torun ${ }^{8}$ have received separate attention. The growing interest in the problems of material science in the architecture of the region is, it seems, the result of a general tendency in medieval art studies which, in recent years, has been more occupied with technological and conservational research on the technique of creating architectural sculpture, its material, and polychrome. In this respect, research on the art in the Teutonic Order's state is still wide open and carries great potential. Preserved fragments require in-depth technological analyses and interdisciplinary deduction in terms of style and semantics, and the relationship between works of art from different centers, the problem of their age (here, the dispute concerning the Golden Gate dating comes to the fore), and relations to cast-stone sculptures require consideration. The prevailing view of architectural evolution has been changing rather dynamically, and it is worth mentioning that this has been influenced by other research as well, for example by the dendrochronology of roof trusses. It requires vigilance and readiness to review the existing paradigms. As a result of the architectural research conducted in recent years, the well-known historical material has been expanding, offering some possibilities for reinterpretation.

In this context, this article presents a fragment which came to light as the result of the archaeological excavation campaign conducted in Kulmerland (today: Chełmno land, ziemia chełmińska) within the framework of the project Castra Terrae Culmensis under the supervision of Prof. Marcin Wiewióra. ${ }^{9}$ It is a minor discovery of small size, but, as it seems, of great "causative power" in terms of revising our knowledge of types, manufacturing techniques, and above all, the actual layers of meaning with regard to figural decorations in the oldest Teutonic strongholds in the Teutonic Order's state in Prussia.

The monument, ${ }^{10}$ which has not yet been published, was discovered on 25 July 2017 during a survey excavation conducted in the territory of a castle in

Architektur im Preußenland. Untersuchungen zur Frage der Kunstlandschaft und -geographie (Petersberg: Imhof Verlag, 2007), 96-97; Wasik, Budownictwo, 223 and 267.

7 Marian Kutzner, "Ceglany detal architektoniczny byłego zamku krzyżackiego w Elblągu," Archeologia Elbigensis 2 ( 1 997): 59-77; Pospieszny, Domus, I 06 - I I 2.

8 Zamek krzyżacki w Toruniu XIII-XXI w. Studium historyczno-architektoniczne z katalogiem detalu architektonicznego ze zbiorów Muzeum Okregowego, praca zbiorowa, Torun 2017.

9 Castra Terrae Culmensis. Na rubieży chrześcijańskiego świata. Projekt NPRH, last modified 30 October 20 I 8, accessed I November 20 I 8, http://projektumk.wixsite.com/castra-terrae.

10 The work was briefly presented by the author in the paper "Nie tylko Złota Brama. Glina jako pierwszy materiał rzeźby i detalu architektonicznego państwa zakonnego w Prusach," at the national Polish scholarly conference Glina w obiektach zabytkowych. Ochrona i konserwacja, organized by the Zarząd Główny Stowarzyszenia Konserwatorów Zabytków (the Historical 
Starogród near Chełmno which no longer exists (see Fig. I). The exact place of its origin is not confirmed, but on the basis of analogies between the sculptures from Elbląg and Malbork one can suppose that it is a part of a decoration from the old castle chapel which functioned until the mid-I 5 th century as a place of worship of Saint Barbara and concentrated on the relics of her skull. ${ }^{11}$ The fragment, only I $2 \mathrm{~cm}$ in height, is a part of a semi-plastic figural representation of the figure of a woman - probably a saint. As a whole, it could measure no more than $40 \mathrm{~cm}$. In its present state, it is a headless bust, from which, however, one can recognize several features concerning the form and iconographic details: an emblem, the modeling of drapery, and the modeling of anatomical details. The figure was facing forward, and clad in a kirtle with narrow sleeves reaching the wrist and a coat taken on the left side: there is an arrangement of niches running under the elbow from the right hip toward the left hip and the base of flat tubular waves of a drapery on the figure's left side. In both hands, she holds an attribute which she presents in front of her. One can recognize that the form of the attribute is a can (a ciborium) with a short pedestal, a round, elongated body, and a cover with a small ball at the end. The figure supports the can on the left hand which is side-faced to the viewer, and with the right hand she grasps its cover from the top. Both forearms appear to have been bent at the elbow, and the right hand is bent perpendicularly in the wrist. Though only such a small part is preserved, the sculpture is of quite a high artistic level. The surface is modeled plastically and quite precisely: the modeling is small, which is especially visible at the base of folds of the drapery. The gesture of the figure is studied and unnatural, which is particularly visible in the arrangement of the right hand - slender with long narrow fingers, modeled separately, and placed on the surface of the cover in such a way that the index finger is moved away and slightly bent, while the middle finger is straight, and the other two, placed more closely to each other, are also slightly bent. Also, the left hand is placed in a studied way: the saint holds the foot of the vessel with her index finger and thumb.

The attempt to determine the original location of the figure remains hypothetical. Nevertheless, one can suppose that the described sculpture was part of a larger gallery of figures which belonged to the architectural decoration of a

Monuments and Art Conservators Association Main Board) together with the Muzeum Zamkowe in Malbork (the Malbork Castle Museum) on 20-22 March 20 i 8.

I Agnieszka Błażewicz, "Skarb relikwiarzowy z kościoła zamkowego w czasach krzyżackich. Dzieje relikwii św. Barbary," in Spotkania Malborskie im. Macieja Kilarskiego, vol. I, ed. Artur Dobry (Malbork: Muzeum Zamkowe, 20 Io), 93-I I2; Agnieszka Błażewicz-Oberda, "Kult świętej Barbary w państwie zakonu krzyżackiego w Prusach," in $Z$ dziejów średniowiecza. Pamięci prof. Jana Powierskiego, ed. Wiesław Długokęcki (Gdańsk: Wydawnictwo Uniwersytetu Gdańskiego, 2010), I I-32. 
portal: a jamb or, as in Malbork, an archivolt base. This assumption is supported by the original size of the sculpture and its fairly plastic volume, as well as, on the other hand - an integral connection with the background.

The art expertise of the Starogród fragment is an important contribution to the knowledge of old manufacturing techniques. Observation of the fracture suggests that the figure could have been squeezed out of the mold, similarly to sculptures made from cast stone. The clay delamination, visible both at the side fracture and from the bottom (see Fig. 2), seems to follow the shape of the mold. Its arrangement suggests the orientation of the structure of the material. A random effect of erosion cannot be excluded here. However, it is probable that we are dealing with a trace of layered clay portioning and pressing it to the mold.

Quite significant holes, visible from the back at the fracture, may be the residue of failed, insufficient pressing of a portion of clay (see Fig. 3). Also the "damage" on the attribute might be the result of failed pressing of the layer of clay in a small element of the mold to its inner surface (see Fig. 4). The surface of the imprint, probably while still slightly moist before drying and firing, was chiseled sculpturally (with knives or flat carving chisels), as indicated by the sharp undercut of the sleeve cuff or sharp lines on the torso running along the hand (see Fig. 5). Next, the figure had to be dried, fired, chiseled, and covered with polychrome whose remnants remain on the surface. A layer of lead white is noticeable in the photo in UV fluorescence (see Fig. 6), which posed a kind of underpaint for painting work from which trace amounts based on iron oxide red and ochre remain. (see Fig. 7 ) $^{\mathrm{I2}}$

From these technical observation, one can draw two important conclusions. Firstly, the workshop probably used a complex mapping technology whose starting point was a model designed for firing shrinkage: at this stage of research it is difficult to establish whether the model was molded in clay or carved in wood. It cannot be dismissed that the mold was wooden, negative, and made on the basis of a drawing model, though it would be technically more difficult and at the same time more advanced in terms of technique. This may provide an opportunity for further research on the detailed working methods of Prussian ceramic workshops. Secondly, the workshop needed repetitive elements and searched for ways to fasten the creative process - otherwise the representation would be molded freehandedly. Thus, there must have been more figures of similar shape at the Starogród portal.

12 Polychrome samples tested by A. Cupa at the Instytut Zabytkoznawstwa i Konserwatorstwa UMK (Nicolaus Copernicus University Institute for the Study and Conservation of Cultural Monuments). 
From this perspective, one can look again at the Golden Gate: chef d'oeuvre of ceramic architectural sculpture from the Teutonic Order's state (see Fig. 8), highly recognized, and cause for multiple hypotheses with regard to style, dating, and semantics. In studies on the sculptures of the portal, these are mainly described with regard to the origins of style and in search for analogies for their basic features - density of the volume and flatness of the layout. To quote from Bogna Jakubowska's classic monograph (here translated into English): "the figural sculptures of the Golden Gate are characterized by [...] blockiness, symmetry and conventionality of approach [...] the impression of the immobility of matter [...]. [The sculptures] have all the typical features of the obsolete style which was present in many sculptural works from the third quarter of the I 3 th century." ${ }^{13}$ At least to some degree, the "hardening" of the forms suggested by the researcher does not seem to be a question of style, but, rather, a consequence of the process of sculpture making. Despite the remarks made in recent years by Anna Błażejewska and Kazimierz Pospieszny, there is still a lack of insightful and comprehensive studies on the techniques of the Golden Gate's decorations: very rich in plasticity and, as it seems, quite uneven when it comes to artistic category. The quality of ornamental detail making definitely exceeds concisely approached figures. The first ones, as justly indicated by Kazimierz Pospieszny, ${ }^{14}$ were being made in a very characteristic way - with the use of clay plasticity and several matrices. Made in the same flat negative mold, probably a wooden one, vine and oak leaves and acanthus twigs of small precise veining were connected in a semi-moist condition to the segments of the concave archivolt (see Fig. 9) and the segments of the capital zones. The fundamental arrangements in the archivolt are fairly repeatable; however, one can see ease in the plastic shaping of leaves, which were being bent and put one on another. The effect of diversity is the result of diversification of the twigs which probably were not made with the use of a matrix, but freehandedly rolled by hand. The plastic wine grapes are of the same size, and it should be assumed that they were made by using one matrix. Twined into the plant ornamentation, small locusts, hybrids, and animals are quite flat and small, and seem to be the result of fairly precise freehand modeling. However, some doubts can be raised when it comes to how the Wise and Foolish Virgins' sculptures, as well as the Ecclesia and the Synagogue, were made. In terms of structure and preparation, these are the elements which are the most "hardened" regarding the whole composition of the portal. The thesis about carving in clay, which is still being repeated in the

13 Jakubowska, Ztota Brama, 32.

14 Pospieszny, Domus, 96-97. 
literature (for example by Anna Błażejewska ${ }^{15}$ and the newest catalogue of Detal architektoniczny $z$ toruńskiego zamku krzyżackiego ${ }^{16}$ ), should definitely be rejected. The usage of this method does not seem to be possible due to technology and the properties of the material. The clay figures must have been formed in a moist material. They could have been a bit sculpted in a semi-moist condition, or even chiseled after firing (with deepening the grooves and smoothening the edges), but certainly not carved using the stonework method, which has been emphasized by Kazimierz Pospieszny. ${ }^{17}$ It could be assumed that, despite significant compositional convergence, each of the sculptures was made separately, freehandedly, in a fairly concise and unsophisticated way. Nevertheless, the observation of the fragment from Starogród indicates that sculptures of similar size (the Malbork Virgins measure 39-4I cm) could have been made with the use of a mold. The analysis of the original figures from the group of the Wise Virgins (namely the first, fourth, and fifth one from the left, see Fig. Io) indicates that the method of repeatable impression could have been used in Malbork as well. The first and the fourth Virgin do not raise doubts in that respect, even though the arrangement of fingers in their left hands and probably their heads were changed. The fifth Virgin could have been remodeled after the impression, while still in moist clay, with adding the coat piping and changing her gesture, but the heads are very similar. The Foolish Virgins on the right side of the portal are much more diversified with regard to expression and poses due to the iconographic tradition; thus, they do not exhibit much convergence even though it is conspicuous that some of their heads are very similar to one another. The sculptures could have been partially modeled free-handedly, and partially with the use of molds; they also could have been made from several repeatable molds and joined before firing (e.g., the heads with the bodies) - this would explain the "mask-like" faces, a feature noticed by Bogna Jakubowska. ${ }^{18}$ It was a standard in such projects to use the double-mapping technique. Examples are the Kołobrzeg candle holder, cast in bronze in $1327,{ }^{19}$ or the figures of the apostles in the castle church at Malbork, made from cast

is Błażejewska, Rzeźba, i 88-i 89.

16 Romualda Uziembło, "Detal architektoniczny z toruńskiego zamku krzyżackiego w zbiorach Muzeum Okręgowego w Toruniu. Katalog," in Zamek krzyżacki w Toruniu XIII-XXI w. Studium historyczno-architektoniczne z katalogiem detalu architektonicznego ze zbiorów Muzeum Okręgowego (Toruń: Muzeum Okręgowe 2017), 84-229.

17 Pospieszny Domus, 96.

18 Jakubowska, Ztota Brama, 30.

19 Monika Jakubek-Raczkowska, "Gotycki świecznik z bazyliki Mariackiej w Kotobrzegu. Nowe spojrzenie na warsztat mistrza Jana Apengetera," in Odlewnictwo w Polsce, Materiaty z VII Sesji Naukowej Rzemiosto artystyczne i wzornictwo w Polsce, ed. Katarzyna Kluczwajd (Toruń: Stowarzyszenie Historyków Sztuki, 2007), 95. 
stone while employing repetitive prototypes. ${ }^{20}$ The "hardening" of the style can be explained by the choice of the repeatable mapping technique which was the reason for the blockiness of the volume and a very slight movement of the fairly shallow drapery. Comparing the Virgins with other details from the Golden Gate shows that the workshop handled with the figural images of larger sizes most poorly. The characteristic "squeezing" of the figures under the architectural frame may indicate an error in calculating the ceramic shrinkage.

Finally, let us return to the exceptional finding from Starogród. The significance of this discovery goes beyond any observation in respect of technique, technology, or even style. There is no question that we are dealing here with a part of the portal decoration which definitely comes from the castle chapel, but at this stage of research it is not possible to say much about its ideological content. The character's attribute $-\mathrm{a}$ round can with a cover - seems to indicate St. Mary Magdalene. Therefore, this portal would probably differ iconographically from the two well-known Teutonic portal layouts in Elblagg and Malbork decorated with ceramic sculptures whose arrangement definitely carried eschatological connotations. The two preserved fragments of the Elbląg sculptures (see Fig. I I) indicate that, similarly to Malbork, the Wise and Foolish Virgins were represented in the portal. This does not change the fact that the small fragment from Starogród comes from yet another portal layout created more or less at the same time, namely at the end of 13 th century or at the beginning of the I 4 th century. It is different when it comes to the stylistics and workshop; moreover, it seems to be at a higher level regarding the workshop, at least when compared to the figures of the Malbork Golden Gate. Thus, its discovery refutes the previously accepted claim that figural portal layouts are distinctive Teutonic works associated with places of the highest rank. Let us remember that, according to Marian Kutzner's thesis, ${ }^{21}$ the Elbląg portal, whose figures were originally much larger than the Malbork ones, would be the first such work connected with the remarkable castle of a provincial master. The Malbork portal would be its imitation; Kazimierz Pospieszny $y^{22}$ has interpreted the Elblag model solution similarly. All the controversies that have arisen lately in connection with the dating of the Golden Gate result from the fact that it is the only piece of work preserved well enough to reconstruct its extensive iconographic arrangement. ${ }^{23}$ Historians' attempts to move its time record forward are justified

20 For the analysis, see: Raczkowski, Monumentalne zespoty, I 33 - I 57.

21 Kutzner, "Ceglany detal," 55-77; later similarly Błażejewska, Rzeźba, 7 I- I 09 and Pospieszny, Domus, I о6-I I 2.

22 Pospieszny, Domus, r o6- I I 2.

23 The scholarly discussion on the Golden Gate has been going on since Ferdynand von Quast's research paper; see Ferdynand Quast, "Beiträge zur Geschichte der Baukunst in Preußen, III: 
by the connection of this arrangement to the change of the castle function - from the convent-castle to the capital-castle. ${ }^{24}$ Also, among the attempts to defend the dating to the years around I 280 , proposed by Bogna Jakubowska, ${ }^{25}$ there is a theory that imitating the portal of the Elblagg chapel should be connected with the nascent idea of moving the capital to Malbork. ${ }^{26}$ Meanwhile, it seems that a similar piece of work from a small castle in Starogród (also unusual due to the fragment's function, but still unequal to the Elblagg one when it comes to rank) indicates that such decorations could have been a standard in the stronghold architecture of the Order around I 300 , and not an exception. The preserved fragments from the portal frames in Grudziądz and Torun, although only ornamental, but also high class and of similar ideological eloquence as the archivolt decorations of the Golden Gate, can only support this theory.

Thus, ceramic architectural sculpture can be considered a phenomenon of much wider range than has previously been accepted. The emphasis regarding its condition can be moved from the exceptional symbol of rank and power toward genius loci of architecture from the first phase of construction campaigns undertaken by the Teutonic Order in Prussia.

\section{SECONDARY SOURCES:}

Błażejewska, Anna. Rzeźba w Prusach Krzyżackich do potowy XIV wieku. Źródta stylu. Toruń: Wydawnictwo Naukowe UMK, 20 I 2.

Błażewicz, Agnieszka. "Skarb relikwiarzowy z kościoła zamkowego w czasach krzyżackich. Dzieje relikwii św. Barbary.” In Spotkania Malborskie im. Macieja Kilarskiego. Vol. I-3, edited by Artur Dobry, 93- I I 2. Malbork: Muzeum Zamkowe, 20 I.

Schloß Marienburg," Neue Provinzial-Blätter I-3, no. I I ( I 85 I): 56-57, however, the discussion has been revived ever since Marian Dygo's article and proposal; see Marian Dygo, "Złota Brama kaplicy zamkowej w Malborku a ideologia władzy Zakonu Niemieckiego w Prusach," in Zakon krzyżacki a spoteczeństwo państwa w Prusach, ed. Zenon Hubert Nowak, Roczniki Towarzystwa Naukowego w Toruniu 86 no. 3 (1995): I 49-165. Later, on the same topic, Sławomir Jóźwiak, "Uwagi nad datacją Złotej Bramy kaplicy zamkowej w Malborku," Komunikaty Mazursko-Warmińskie 3 (2003): 4 I 5-4 I 8; Bernard Jesionowski, "Kościół Najświętszej Marii Panny na zamku w Malborku - nowe odkrycia i interpretacje jego dziejów," Studia Zamkowe 2 (2006): 82-88.

24 Dygo, "Złota Brama” I 49-165; Sławomir Jóźwiak, "Uwagi nad datacją Złotej Bramy kaplicy zamkowej w Malborku," Komunikaty Mazursko-Warmińskie 3 (2003): 4 I 5-4 I 8.

25 Jakubowska, Ztota Brama, 45.

26 Jesionowski, "Kościól," 67-96. 


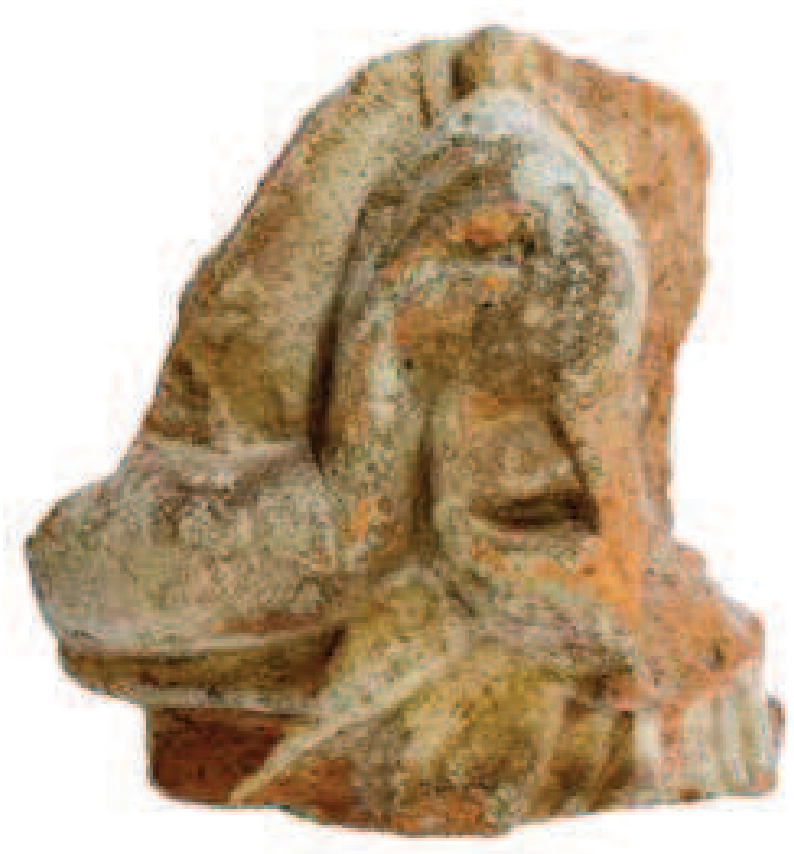

Fig I. Author of the photograph: Juliusz Raczkowski

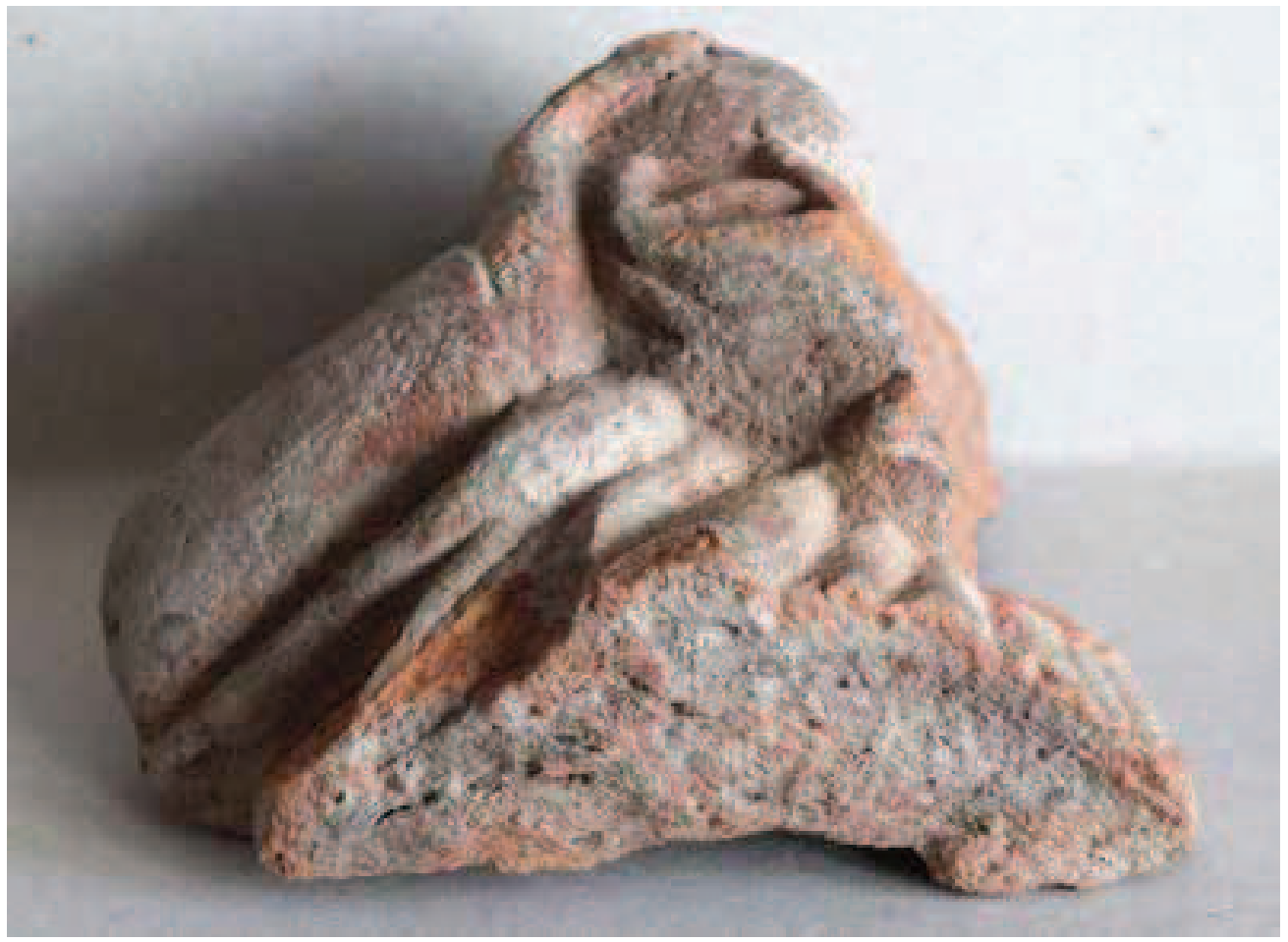

Fig 2. Author of the photograph: Juliusz Raczkowski 
$[350]$

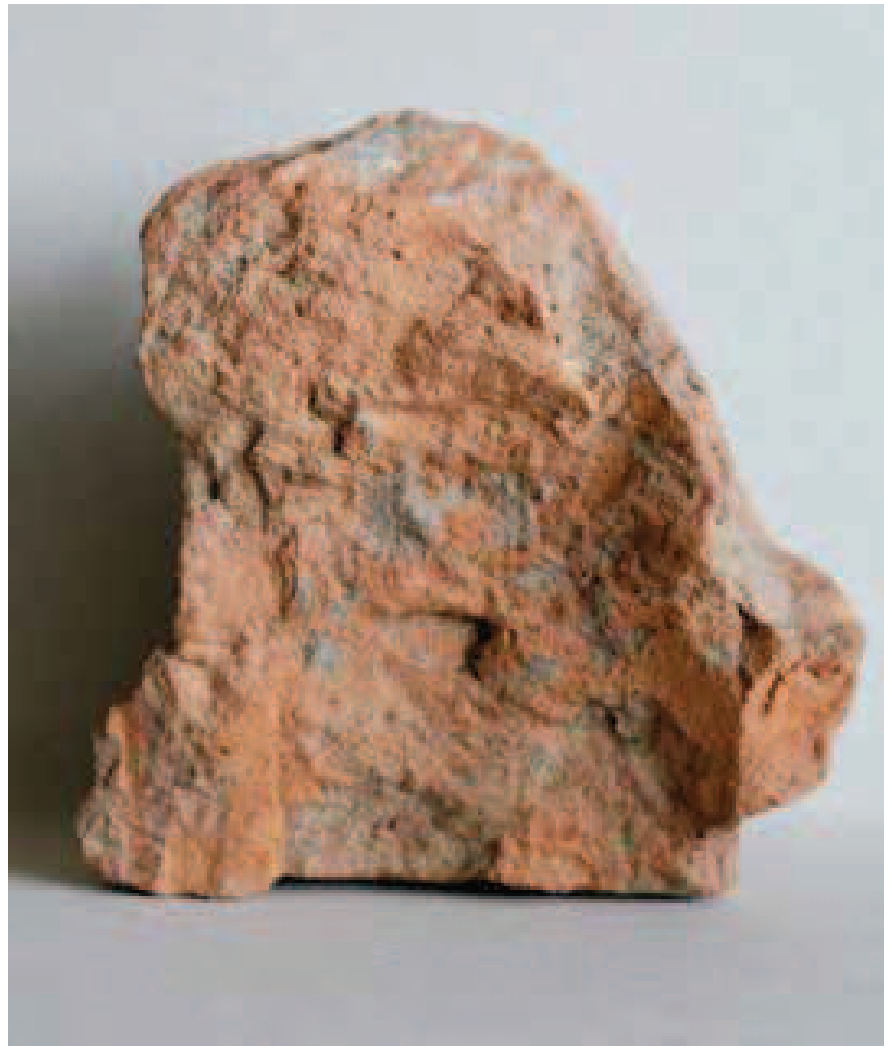

Fig 3. Author of the photograph: Juliusz Raczkowski

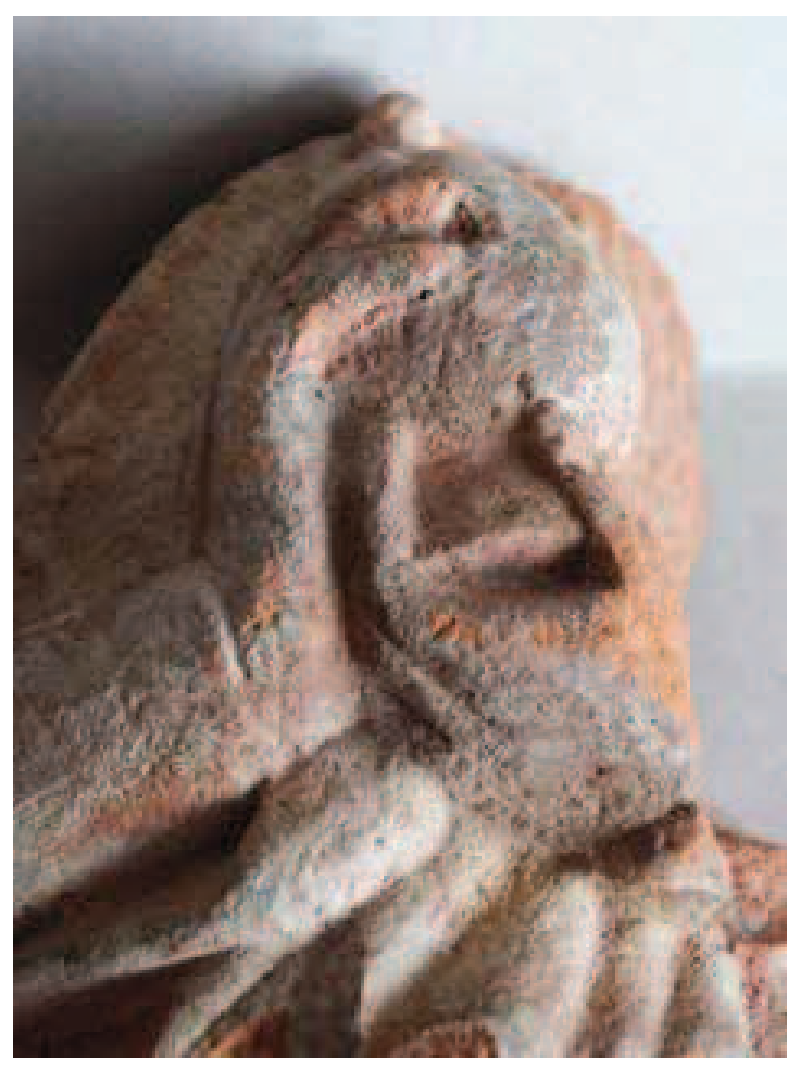

Fig 4. Author of the photograph: Juliusz Raczkowski 


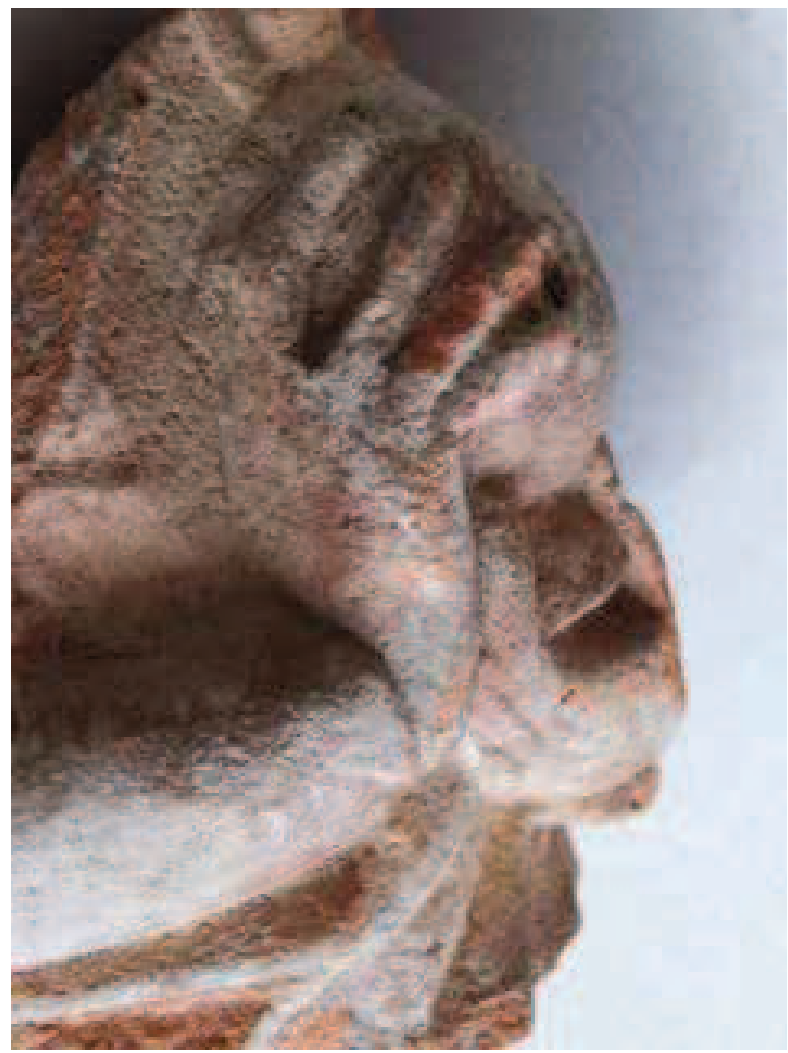

Fig. 5. Author of the photograph: Juliusz Raczkowski

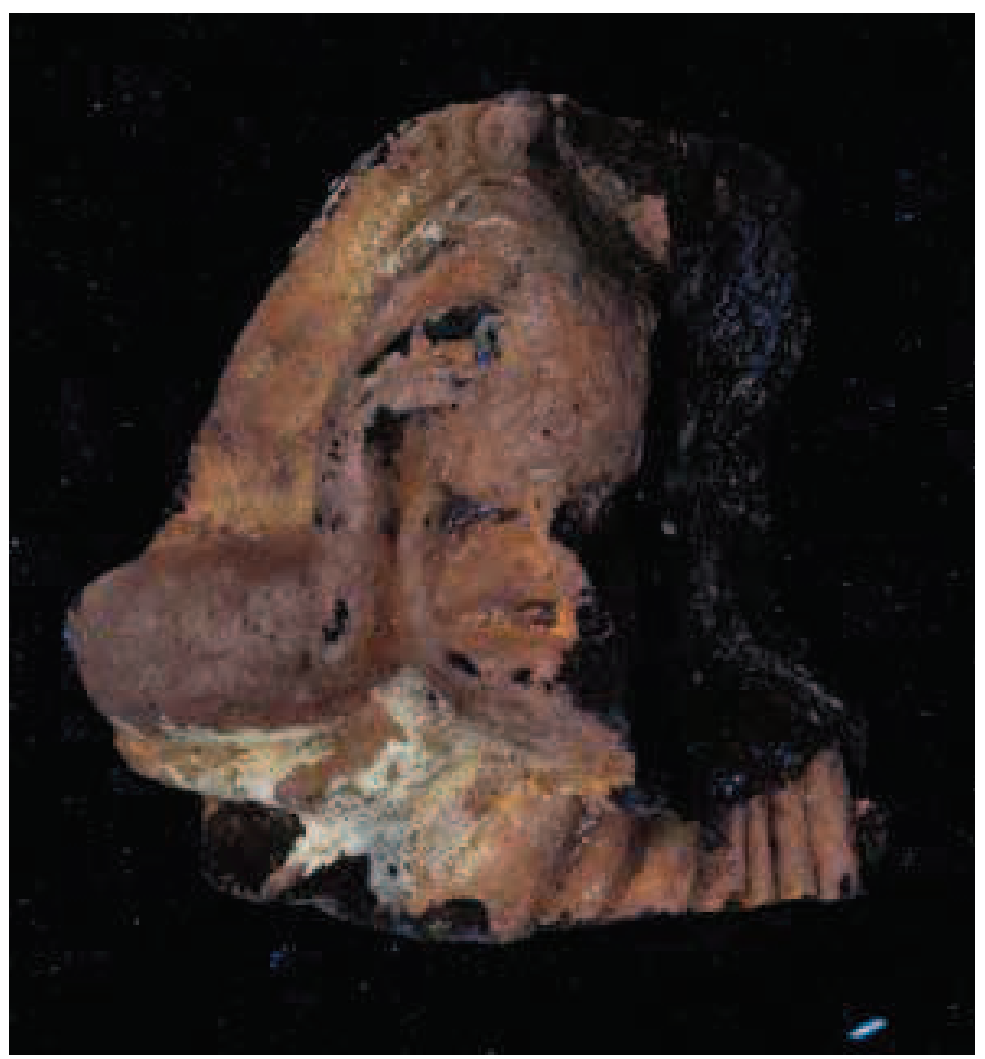

Fig. 6. Author of the photograph: Adam Cupa 


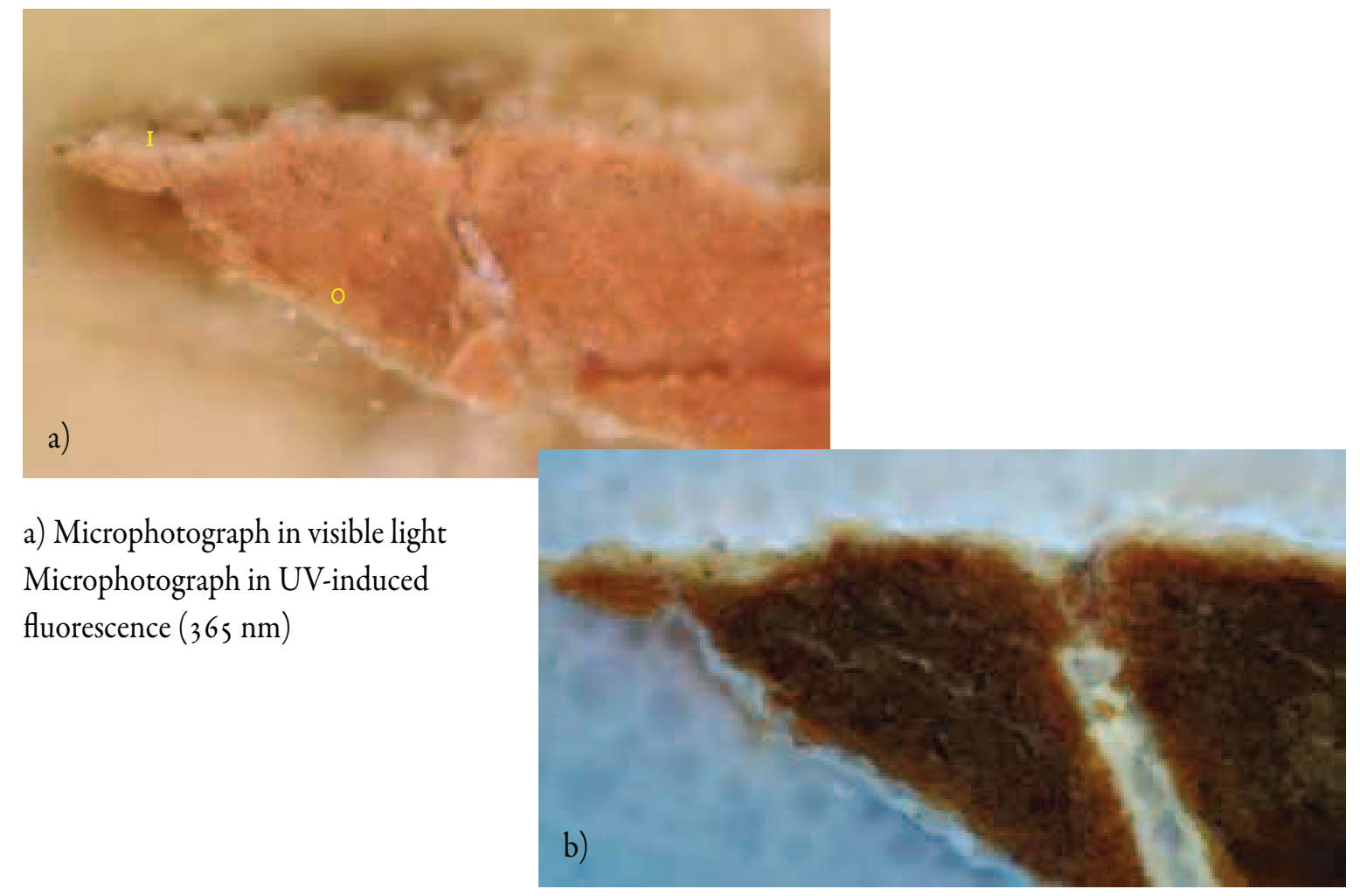

\begin{tabular}{|c|l|l|l|}
\hline No & LAYER & \multicolumn{1}{|c|}{ CHEMICAL COMPOSITION } & TYPe OF BINDER \\
\hline I. & grey & ceruse $2 \mathrm{PbCO}_{3} \cdot \mathrm{Pb}(\mathrm{OH})_{2}$, chalk $\mathrm{CaCO}_{3}$, ochre, iron red $\mathrm{Fe}_{2} \mathrm{O}_{3}$, & most likely carbonate \\
\hline o. & Red - brick & $\begin{array}{l}\text { compounds: of calcium } \mathrm{Ca} \text {, iron } \mathrm{Fe} \text {, silicon } \mathrm{Si} \text {, potassium } \mathrm{K} \text {, tita- } \\
\text { nium Ti, manganese } \mathrm{Mn} \text { i aluminium } \mathrm{Al} .,\end{array}$ & --- \\
\hline
\end{tabular}

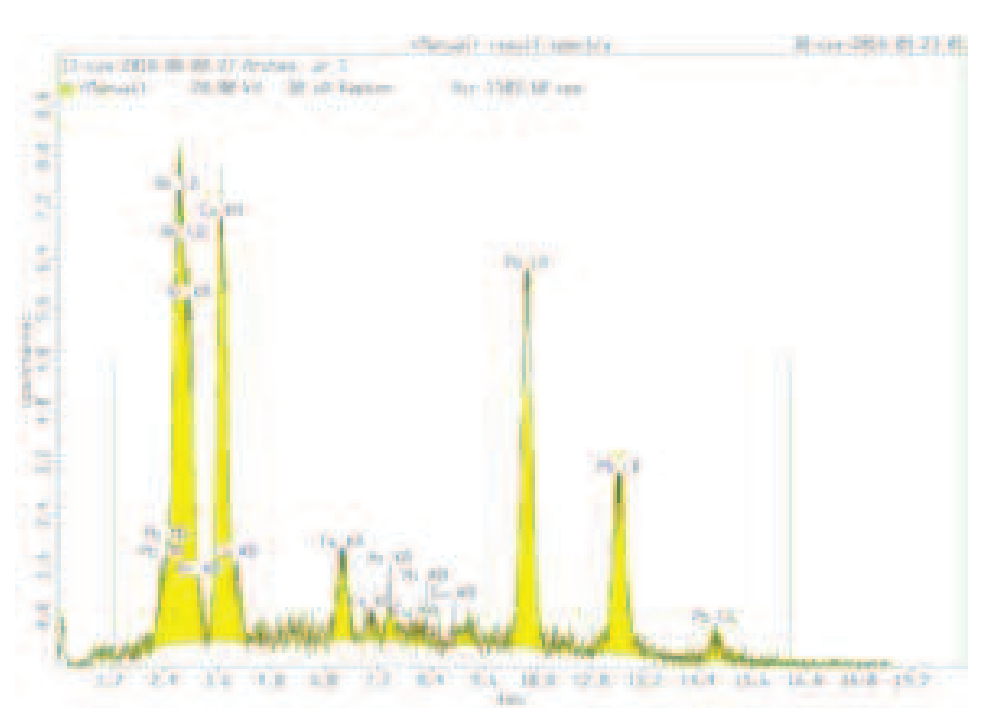

c) X-ray fluorescent analysis of the sample $\mathrm{I}$ : $\mathrm{Ca}, \mathrm{Pb}, \mathrm{Fe}$.

Fig. 7. Author of the photographs: Adam Cupa 


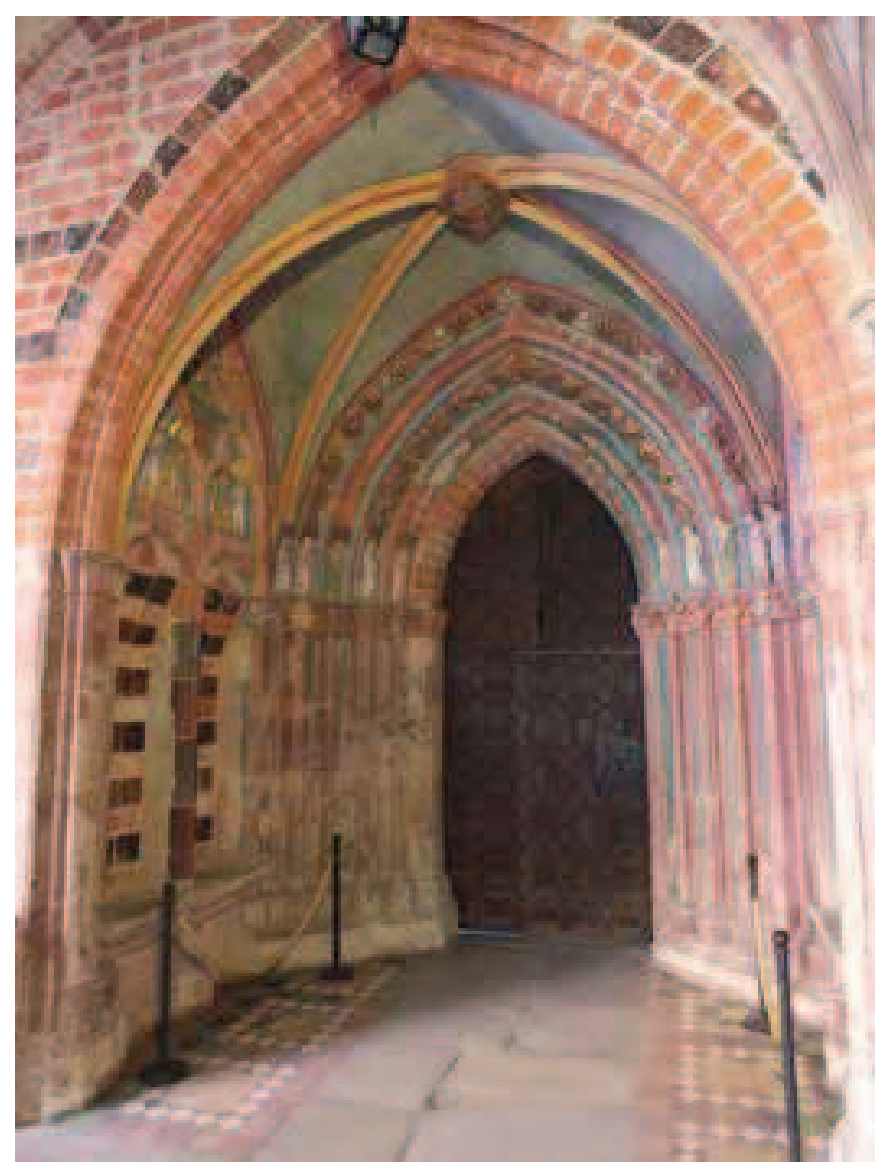

Fig. 8. Author of the photograph: Juliusz Raczkowski

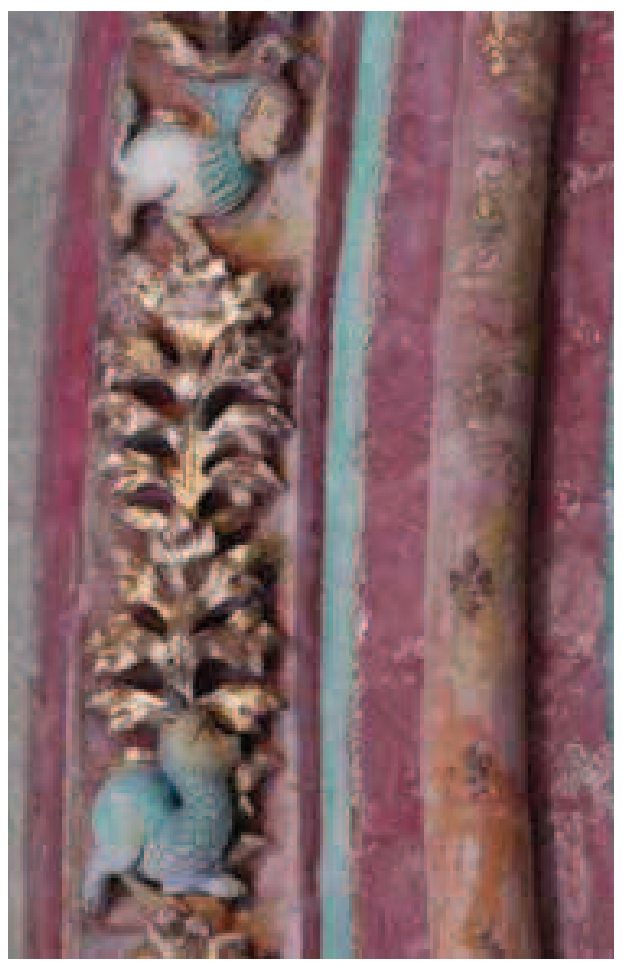

Fig. 9. Author of the photograph: Juliusz Raczkowski 
$[354]$

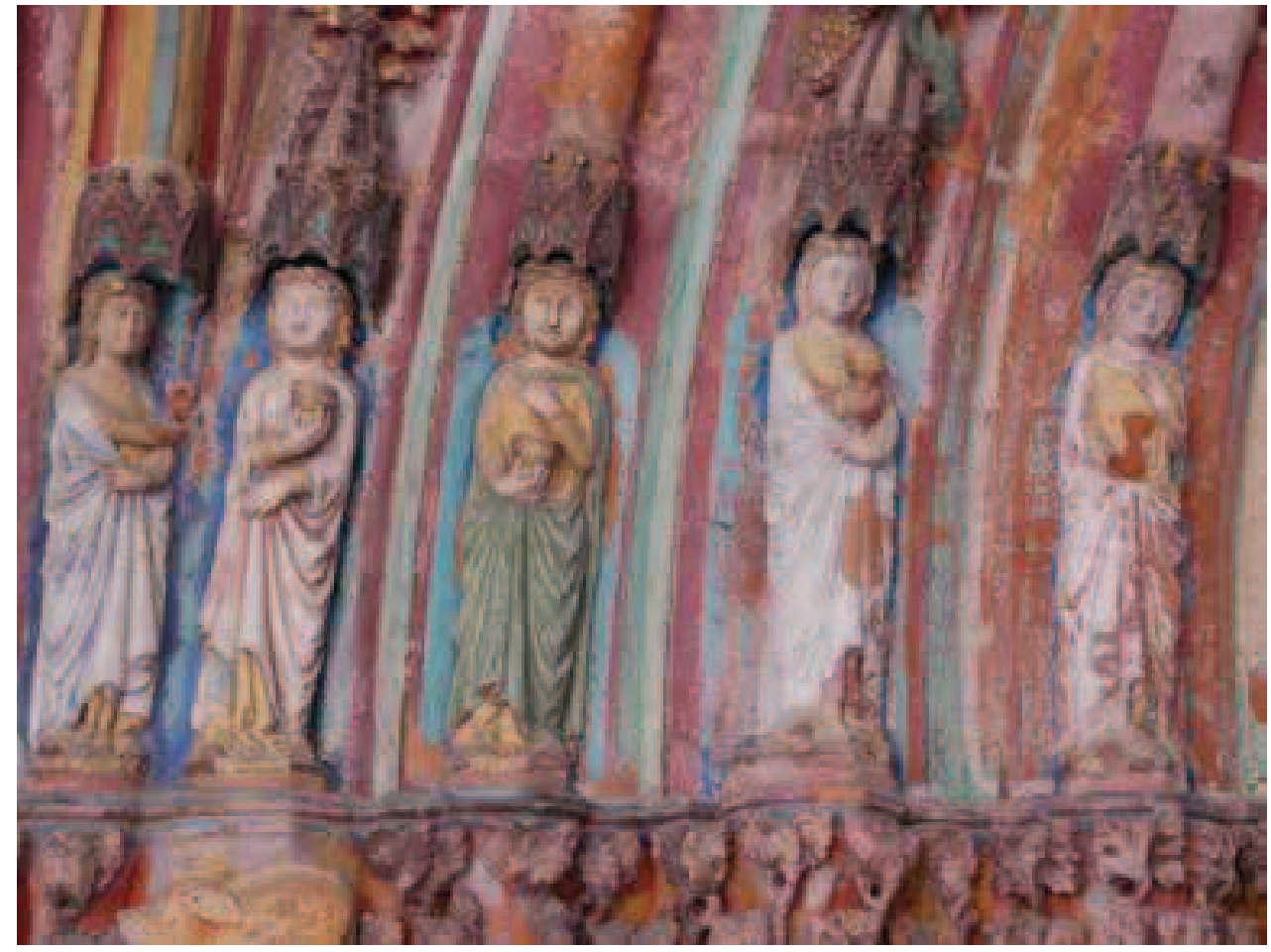

Fig. I . Author of the photograph: Juliusz Raczkowski

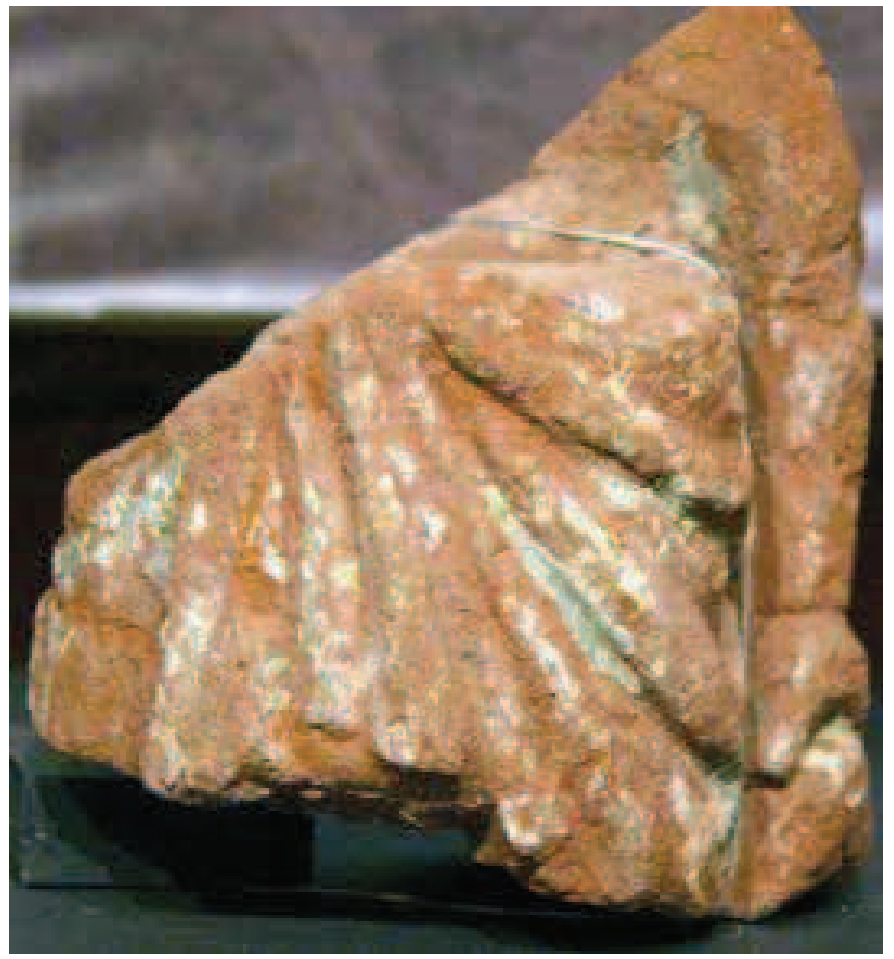

Fig. I I. Author of the photograph: Juliusz Raczkowski 
Błażewicz-Oberda, Agnieszka. "Kult świętej Barbary w państwie zakonu krzyżackiego w Prusach." In $Z$ dziejów średniowiecza. Pamięci prof. Jana Powierskiego, edited by Wiesław Długokęcki, I I-32. Gdańsk: Wydawnictwo Uniwersytetu Gdańskiego, 20 I.

Castra Terrae Culmensis. Na rubieży chrześcijańskiego świata. Projekt NPRH. Last modified 30 October 20 18. Accessed I November 20 I 8. http://projektumk.wixsite.com/ castra-terrae.

Domagała, Roman. "Detale architektoniczne z zamku krzyżackiego w Toruniu." In Komunikaty na sesję naukowa poświęcona dziejom sztuki Pomorza, edited by Jerzy Frycz, I 3-2 I. Toruń: Stowarzyszenie Historyków Sztuki, 1966.

Domagała, Roman. "Stała wystawa na zamku krzyżackim." Rocznik Muzeum Okregowego $w$ Toruniu 3 (1968): 1 25- I 29.

Dygo, Marian. "Złota Brama kaplicy zamkowej w Malborku a ideologia władzy Zakonu Niemieckiego w Prusach." In Zakon krzyżacki a spoteczeństwo państwa w Prusach, edited by Zenon Hubert Nowak, Roczniki Towarzystwa Naukowego w Toruniu 86 no. 3 (1995): I 49-165.

Herrmann, Christopher. Mittelalterliche Architektur im Preußenland. Untersuchungen zur Frage der Kunstlandschaft und -geographie. Petersberg: Imhof Verlag, 2007.

Jakubek, Magdalena, Frank Schlütter, Wioleta Oberta, Jadwiga W. Łukasiewicz. "Medieval Gypsum Mortars Used for Architectural Details in the Castle of the Teutonic Order in Torun, Poland." In Historic Mortars and RILEM TC 203-RHM Final Workshop HMC 20Io, Proceedings of the $2^{\text {nd }}$ Conference and of the Final Workshop of RILEM $T C$ 203-RHM, edited by Jan Válek, Caspar Groot, and John J. Hughes, 227-230. Bagneux: RILEM Publications 2009 / Red Hood, NY: Curran Associates, Inc., 20 I I. Jakubek, Magdalena. "Gotyckie detale architektoniczne z zapraw gipsowych z terenu państwa krzyżackiego w Prusach. Problematyka technologiczna i konserwatorska." $\mathrm{PhD}$ dissertation, Uniwersytet Mikołaja Kopernika, 20 I 5.

Jakubek, Magdalena. "Tzw. sztuczny kamień w średniowiecznych Prusach - nowe uwagi o materiale." In Claritas et consonantia: funkcje, formy $i$ znaczenia $w$ sztuce średniowiecza. Ksiega poświęcona pamięci Kingi Szczepkowskiej-Naliwajek w dziesiata rocznice śmierci, edited by Monika Jakubek-Raczkowska and Juliusz Raczkowski, 477-495. Toruń-Warszawa: Wydział Sztuk Pięknych UMK/Stowarzyszenie Historyków Sztuki, 2017.

Jakubek-Raczkowska, Monika. "Gotycki świecznik z bazyliki Mariackiej w Kołobrzegu. Nowe spojrzenie na warsztat mistrza Jana Apengetera." In Odlewnictwo w Polsce, Materiaty $z$ VII Sesji Naukowej Rzemiosto artystyczne $i$ wzornictwo $w$ Polsce, edited by Katarzyna Kluczwajd, 9 I- I06. Toruń: Stowarzyszenie Historyków Sztuki, 2007.

Jakubowska, Bogna, Ztota Brama w Malborku. Apokaliptyczne bestiarium w rzeźbie średniowiecznej. Malbork: Muzeum Zamkowe w Malborku, I989.

Jesionowski, Bernard. "Kościół Najświętszej Marii Panny na zamku w Malborku - nowe odkrycia i interpretacje jego dziejów." Studia Zamkowe 2 (2006): 67-96.

Jesionowski, Bernard. "Opis architektury i dzieje budowlane kościoła Najświętszej Marii Panny w zespole zamkowym w Malborku." In Zamek Wysoki w Malborku. 
Interdyscyplinarne badania skrzydta pótnocnego, edited by Maria Poksińska, 59-76. Malbork-Toruń-Łódź: Muzeum Zamkowe, 2006.

Jurkowlaniec, Tadeusz. Gotycka rzeźba architektoniczna w Prusach, Wrocław-Warszawa-Kraków-Gdańsk-Łódź: Wydawnictwo Polskiej Akademii Nauk, i 989.

Jóźwiak, Sławomir. "Uwagi nad datacją Złotej Bramy kaplicy zamkowej w Malborku.” Komunikaty Mazursko-Warminskie 3 (2003): 4I 5-4I 8.

Kutzner, Marian, "Ceglany detal architektoniczny byłego zamku krzyżackiego w Elblągu." Archeologia Elbigensis 2 ( 1 997): 59-77.

Kutzner, Marian. "Backsteinelementen der ältesten Deutschordensburgen in Preussen." In Burgen kirchlichen Bauherren. Vol. 6, edited by Wartburg-Gesellschaft zur Erforschung von Burgen und Schlössern in Verbindung mit dem Germanischen Nationalmuseum, 37-48. Forschungen zu Burgen und Schlössern. München: Germanisches Nationalmuseum, $200 \mathrm{I}$.

Mroczko, Teresa. Architektura gotycka na Ziemi Chetmińskiej. Warszawa: Państwowe Wydawnictwo Naukowe, 1980.

Pospieszny, Kazimierz. Domus Malbork: zamek krzyzacki w typie regularnym. Toruń: Wydawnictwo Naukowe UMK, 20 I 4.

Quast, Ferdynand. "Beiträge zur Geschichte der Baukunst in Preußen, III: Schloß Marienburg.” Neue Provinzial-Blätter I -3, no. I I ( I 8 5 I): 56-57.

Raczkowski, Juliusz. Monumentalne zespoty kolegium apostolskiego na terenie dawnego państwa zakonnego w Prusach. Pelplin: Wydawnictwo Bernardinum, 20 I 3.

Raczkowski, Juliusz. "Kolos Malborski: problematyka warsztatowa i styloznawcza." In Monumentalna figura Madonny na kościele NMP w Malborku. Konteksty historyczne, artystyczne i konserwatorskie, edited by Janusz Hochleitner, 83-93. Malbork: Muzeum Zamkowe w Malborku, 20 I 5.

Schlütter, Frank, Magdalena Jakubek, and Herbert Juling. "Charakterisierung und Eigenschaften historischer Gipsmörtel aus unterschiedlichen Epochen und Anwendungsgebieten." In Gips als Baugrund, Mörtel und Dekorationsmaterial, edited by Institut Für Steinkonservierung, e.V., 49-59. IFS Bericht 42. Mainz: Institut für Steinkonservierung, e.V., $20 \mathrm{I} 2$.

Schlütter, Frank. "Mittelalterlicher Hochbrandgips." In 8oo Jahre Kunststein - vom Imitat zum Kulturgut. Beiträge des 6. Konservierungswissenschaftlichen Kolloquiums in Berlin / Brandenburg am 8. November in Potsdam, edited by Bärbel Arnold, 27-39. Worms: Potsdamer Verl.-Buchhandlung, 20 I 2.

Uziembło, Romualda. "Detal architektoniczny z toruńskiego zamku krzyżackiego w zbiorach Muzeum Okręgowego w Toruniu. Katalog." In Zamek krzyżacki w Toruniu XIII-XXI w. Studium historyczno-architektoniczne z katalogiem detalu architektonicznego ze zbiorów Muzeum Okręgowego, 84-229. Toruń: Muzeum Okręgowe 2017.

Wasik, Bogusz. Budownictwo zamkowe na ziemi chetminskiej (od XIII do XV wieku). Toruń: Wydawnictwo Naukowe UMK, 20 I 6.

Wilm, Hubert. Gotische Tonplastik in Deutschland. Augsburg: Benno Filser, I 929. 
Zamek krzyżacki w Toruniu XIII-XXI w. Studium historyczno-architektoniczne z katalogiem detalu architektonicznego ze zbiorów Muzeum Okręgowego. Toruń: Muzeum Okręgowe, 20 I 7.

Zawadzka, Katarzyna. "Portal bramy wjazdowej do zamku krzyżackiego w Bierzgłowie." Rocznik Torunski 37 (2010): 7-36. 